\title{
ОЦІНЮВАННЯ ЯКОСТІ ФУНКЦІЙ УПРАВЛІННЯ НА ПІДПРИЕМСТВАХ РЕСТОРАННОГО БІЗНЕСУ
}

\section{EVALUATION OF QUALITY OF MANAGEMENT FUNCTIONS AT RESTAURANT BUSINESS ENTERPRISES}

\author{
Бедрадіна Ганна Костянтинівна \\ кандидат економічних наук, доцент, \\ Одеський національний економічний університет \\ ORCID: https://orcid.org/0000-0001-8202-8709 \\ Мостова Катерина Антонівна \\ аспірант, \\ Одеський національний економічний університет \\ ORCID: https://orcid.org/0000-0002-6394-9497
}

\author{
Bedradina Ganna, Mostova Kateryna \\ Odessa National University of Economics
}

\begin{abstract}
Стаття присвячена фрормуванню новітніх підходів до оцінювання якості функцій управління на підприємствах ресторанного бізнесу. Оцінювання якості управління повинно стати невід'ємною частиною процесного менеджменту на підприємствах ресторанного бізнесу, що в свою чергу дасть можливість переорієнтації цільових критеріїв, надання нового значення функціям управління та окреслення векторів удосконалення бізнес-процесів підприємств ссери послуг, що сприятиме втіленню їх основних бізнес-цілей. Методичний підхід, який пропонується, передбачає визначення інструментарію оцінювання рівнів якості управління та їх вплив на загальний стан якості менеджменту в конкретному підприємстві галузі. Згруповані результати експертних оцінок щодо якості фрункцій управління на досліджених підприємствах дають змогу отримати більш точну картину стану управлінської роботи.
\end{abstract}

Ключові слова: оцінювання, якість, ффункції управління, підприємство ресторанного бізнесу.

Статья посвящена фрормированию новых подходов к оценке качества функций управления на предприятиях ресторанного бизнеса. Оценка качества управления должна стать неотъемлемой частью процессного менеджмента на предприятиях ресторанного бизнеса, что в свою очередь позволит переориентации целевых критериев, придания нового значения фрункциям управления и определения векторов усовершенствования бизнес-процессов предприятий сореры услуг, что будет способствовать воплощению их основных бизнес-целей. Предлагаемый методический подход предполагает определение инструментария оценки уровней качества управления и их влияние на общее состояние качества менеджмента в конкретном предприятии отрасли. Сгруппированные результаты экспертных оценок качества фрункций управления на исследованных предприятиях позволяют получить более точную картину состояния управленческой работы.

Ключевые слова: оценка, качество, функции управления, предприятие ресторанного бизнеса.

The peculiarity of the functioning of the restaurant business in economic and social manifestations is to ensure the quality of life of the population by meeting physiological needs. The effectiveness of any restaurant business depends on many factors, which include competitive positioning, specifics and technology of creating a restaurant brand, which will ensure high customer loyalty, defining clear strategic prospects for development, optimal financial and marketing activities. Significant dynamism and uncertainty of the current socio-economic environment, increasing competition in the consumer market require the management of the restaurant business new creative management decisions to ensure effective operation and sustainable development. The escalation of the pandemic and the oscillating lockdown are creating a depressing mood in the restaurant business. The realities of further uncertainty require the transformation of the restaurant's business environment and the strengthening of staff competencies suitable for anti-crisis response. However, the success of the restaurant business depends on the efficiency of business processes, which requires the formation of new approaches to assessing the quality of management functions. Assessing the quality of management should become an integral part of process management in the restaurant business, which in turn will reorient the target criteria, give new meaning to management functions and outline 
vectors for improving business processes of service enterprises, which will contribute to their main business goals. The proposed methodological approach involves determining the tools for assessing the levels of management quality and their impact on the overall state of management quality in a particular enterprise industry. The grouped results of expert assessments of the quality of management functions in the surveyed enterprises allow to obtain a more accurate picture of the state of management work. The most competent and timely assessment of the quality of management will allow restaurant businesses to develop a set of operational management decisions and build a philosophy of future management tactics.

Keywords: evaluation, quality, management functions, restaurant business.

Постановка проблеми В реаліях сьогодення велика кількість суб'єктів ресторанного бізнесу знаходяться у досить не стабільному становищі та працюють на пороговому рівні фрінансової спроможності. Здійснення діяльності у мовах ризиків, що спричинила пандемія COVID-19 таких, як втрата конкурентних переваг і репутації закладу, кадровий голод, спонукає ресторанний менеджмент до комплексного підходу щодо оцінювання та переосмислення фрункцій управління направлених перш за все на безпеку та якість послуг, які пропонують. На нашу думку саме грамотне та своєчасне оцінювання якості менеджменту, дасть змогу суб'єктам ресторанного бізнесу розробляти комплекс оперативних управлінських рішень та будувати орілософрією майбутніх тактик управління. Актуальність вказаних проблем зумовили та визначили мету дослідження.

Аналіз останніх досліджень і публікацій. Вагомий внесок у теоретичне дослідження сутності управління бізнес-процесами підприємства, оптимізації управління ними здійснили С. О. Ареф'єв, А. А. Поцелуйко (2017), І. П. Отенко, М. В. Харнам, Р. П. Шкребень (2020), М. С. Крамар, В. Г. Щербак (2019). Також широко напрацьована тема інноваційних методів удосконалення бізнес-процесів Ю. В. Литюга (2018), Н. П. Юрчук (2018), зокрема стосовно питань інноваційних методів управління бізнес-процесами на підприємствах сорери послуг: С. В. Барановська, А. А. Ружицький, Ю. В. Михайлович (2019). Дослідженню ролі бізнес-процесів у структурі менеджменту підприємства присвячено праці зарубіжних вчених, зокрема: A. Lemaska-Majdzik, M. Okreglicka (2015), M. Alstayn, Dzh. Parker, S. Chaudari (2017).

Виділення невирішених раніше частин загальної проблеми. Незважаючи на значну зацікавленість науковців сутністю удосконалення та оцінювання фрункціонального управління та характерними особливостями їх реалізації на підприємствах ссрери послуг, комплексний підхід у дослідженні даних питань відсутній, особливо це актуально для готельно-ресторанної галузі як найбільш вразливої до зовнішніх коливань.
Формулювання цілей статті (постановка завдання). Досягнення високої якості послуг та належної якості обслуговування споживачів на підприємствах ресторанного бізнесу неможливе без участі людей у процесі виробництва та реалізації кінцевого продукту. Не випадково один 3 принципів всезагального управління якістю (Total Quality Management) сфрормульовано так: «Підвищити якість можна тільки зусиллями всіх працівників підприємства» [1, с. 237-244]. Отже, людський фрактор або, якщо висловлюватися точніше, персонал закладу вагомо впливає на якісну роботу всього підприємства.

Суттєвою відмінністю підприємств ресторанного господарства $€$ те, що на ринку готельно-ресторанних послуг вони представлені переважно малими підприємствами, а за формою власності - приватними. Очевидно, із зазначених причин більшість підприємств запроваджує прості фуункціональні структури управління [2, с. 86-92].

На рівні підприємства суб'єктом управління виступає керівництво організації, працівники апарата управління, які здійснюють управлінські фрункції для досягнення поставленої мети, а саме - розвитку свого підприємства $[3$, c. 543-544].

Якщо розглядати процес управління розвитком підприємства як соціально-економічної системи з точки зору його послідовності, то першим його етапом виступатиме знаходження та встановлення цілей підприємства.

Потім наступає етап планування, тобто дослідження та визначення шляхів досягнення цілей. Планування тісно пов'язане 3 організацією. Тільки тоді, коли планують, й можна організувати процес, а в подальшому визначити, хто та за що відповідає (структура управління процесом), що й у якій послідовності варто зробити (хід процесу), які кошти для цього необхідні (забезпечення процесу) тощо. Після цього вирішують питання, пов'язані з мотивацією учасників даного процесу та організацією контролю за реалізацією управлінських рішень [4, с. 134-138]. Загальну схему процесу управління підприємством показано на рис. 1.

Виклад основного матеріалу дослідження. Першочерговим завданням для 


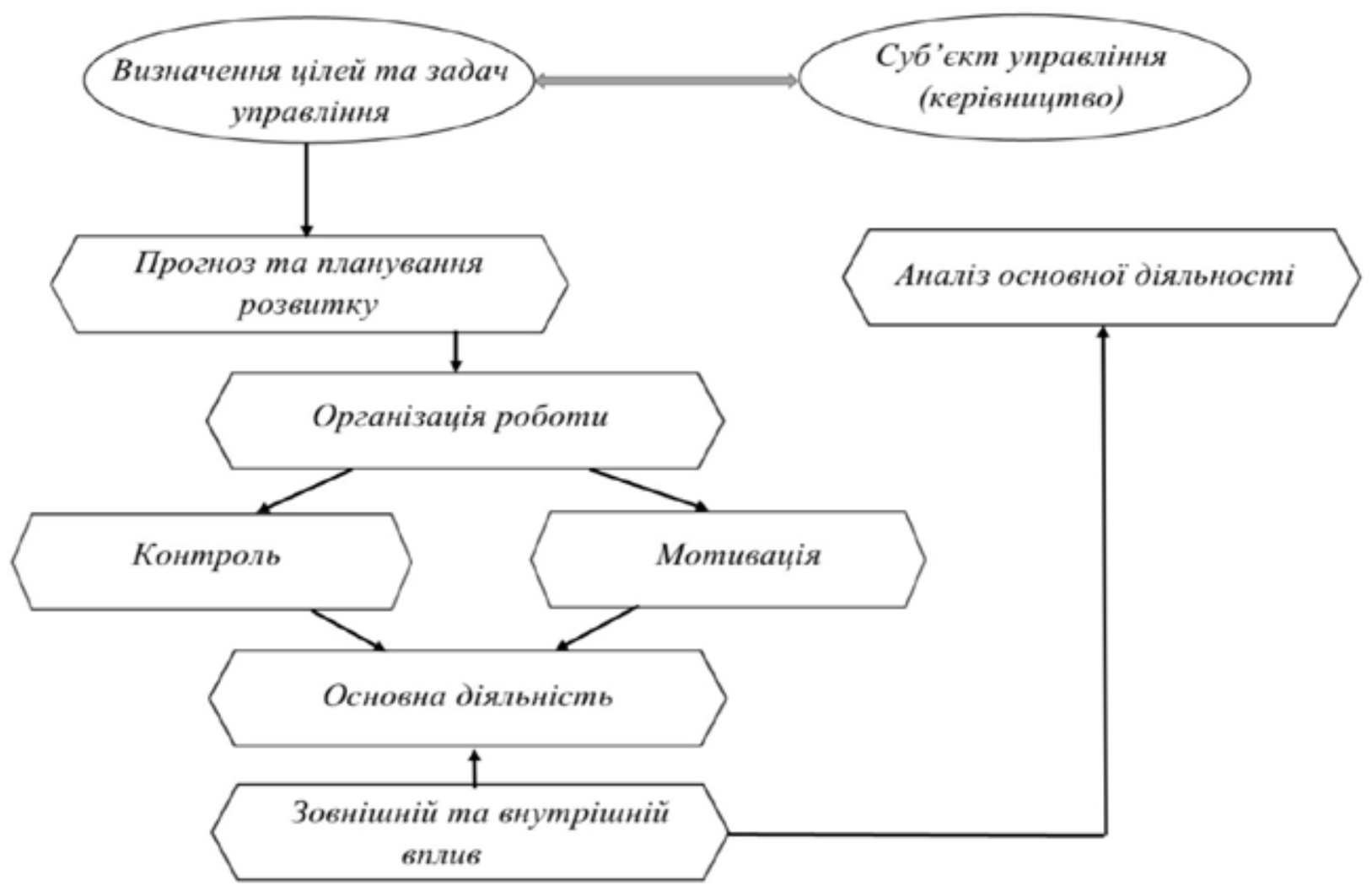

Рис. 1. Схема процесу управління розвитком підприємства ресторанного бізнесу

Джерело: складено автором на основі [3]

вивчення та аналізу якості управління на підприємстві ресторанного бізнесу $є$ визначення показників, за якими буде проведено оцінювання. Можна скористатися економічними показниками, що характеризують основні напрями господарської діяльності підприємства: виробничий, фрінансовий, маркетинговий, інвестиційний. Саме такий підхід пропонують англійські фрахівці Р. Каплан та Д. Нортон [5, с. 122-129]. В основі такого підходу покладено припущення: якщо ці показники зросли за аналізований період, то менеджмент управління упорався зі своїми завданнями. Можливо такий підхід є прийнятним при рішеннях власниками бізнесу щодо додаткових інвестицій у діяльність підприємства, загальному оцінюванні діяльності організації, проте для отримання актуальної картини якості управління за кожною його функцією пропонована методика може бути вдосконалена [6, с. 23-29]. Тому в межах нашого дослідження маємо намір здійснити аналіз якості управління на підприємствах ресторанного бізнесу, заснований на оцінюванні рівня виконання основних, базових фрункцій управління на підприємстві [7, с. 423-429].

Отже, включимо до числа основних фрункцій управління такі: планування, організація, мотивація, контроль, координація.
Дослідження якості основних фрункцій управління проводилося на прикладі ресторанів м. Одеси. Для експериментальних досліджень обрано десять ресторанів однакової організаційно-правової фрорми ведення бізнесу і масштабів діяльності, а також які розраховані на приблизно однаковий сегмент споживчого ринку (табл. 1). Експертні дослідження проводилися спеціалістами консалтинговою компанії «Ресторанний консалтинг», м. Одеса в співробітництві з авторами.

Експертами було запропоновано наступні умови щодо оцінювання функцій управліннянайвища оцінка по кожній з двадцяти п'яти категорій (питань), які оцінюють складає 4 бали. Відповідно максимальний результат по кожній 3 п'яти функцій управління 20 балів.

Середній бал по кожному з двадцяти п'яти питань обчислювався нами за фрормулою:

$$
J_{c .}=\frac{J_{\text {K. }}+J_{\text {M. }}+J_{\text {H.e. }}}{3}
$$

де $J_{c .}$ - середній бал з кожного питання, що зазначалось в анкеті;

$J_{\text {к. }}$ - середня оцінка керівника ресторану;

$J_{м .}$ - середня оцінка менеджерів;

$J_{\text {н.е. }}$ - середня оцінка незалежних експертів. 
Таблиця 1

Ресторани обрані для експериментальних досліджень якості функцій управління

\begin{tabular}{|c|c|c|}
\hline РЕсторАни & $\begin{array}{c}\text { Умовна позначка } \\
\text { підприємства }\end{array}$ & Вид організації \\
\hline YUG & 01 & ресторан \\
\hline Риба & 02 & ресторан \\
\hline REEF & 03 & ресторан \\
\hline Di Mare & 04 & ресторан \\
\hline Tерраса Cи Bью & 05 & ресторан \\
\hline Kador Restarant & 06 & ресторан \\
\hline Ассоль & 07 & ресторан \\
\hline Яхта & 08 & ресторан \\
\hline Колумбус & 09 & ресторан \\
\hline Маман біля моря & 10 & ресторан \\
\hline
\end{tabular}

Джерело: складено автором

Передусім розглянемо результати опитування щодо якості виконання першої фрункції - планування. Їх надано в табл. 2.

Аналізуючи дані табл. 2. щодо результатів порівняльного оцінювання якості управління за фуункцією «Планування», безумовним лідером $є$ підприємство «04», яке за даним показником лише на два бали відстає від максимального результату. Також спостерігається суттєвий відрив трійки лідерів, до складу яких увійшли підприємства «03», «06» і «08», від інших ресторанних підприємств. Далі слідують підприємства-«середняки», до складу яких увійшли підприємства «01», «02» «06», «09». До яскраво виражених аутсайдерів варто віднести підприємства «07», «10»: за рівнем показника вказані підприємства відстають від максимального результату лідера на одинадцять балів, а підприємство «05» на дев'ять балів.
За оцінкою експертів, планування на підприємстві «04» відповідає вимогам ринку та цілям підприємства. Експерти звертають увагу, що на початку нового фрінансового року на підприємстві складається поточний річний план із визначенням запланованих показників успішності ресторану, фрінансових надходжень за рахунок потенційних та залучених клієнтів, розробляється кошторис витрат по всіх статтях загального прибутку, видатках. Особливе значення приділяється плануванню ресурсів, оскільки керівництво намагається не брати позики на здійснення діяльності, зважаючи наперед на власні можливості. У скороченому, але більш деталізованому вигляді такий план складається щоквартально та щомісячно. Проте ця діяльність проводиться несистематично та потребує вдосконалення.

Аналогічно було проведено оцінювання якості інших фрункцій управління. Після отри-

\section{Результати оцінювання якості управління за функцією «Планування» на підприємствах ресторанного господарства}

\begin{tabular}{|c|c|c|c|c|c|c|c|c|c|c|c|}
\hline \multirow{2}{*}{$\begin{array}{c}\text { Найменування фрункції } \\
\text { управління }\end{array}$} & \multirow{2}{*}{$\begin{array}{l}\text { Максимальна } \\
\text { оцінка }\end{array}$} & \multicolumn{10}{|c|}{ Фактична оцінка } \\
\hline & & 01 & 02 & 03 & 04 & 05 & 06 & 07 & 08 & 09 & 10 \\
\hline \multicolumn{12}{|l|}{ 1. Планування } \\
\hline $\begin{array}{l}\text { 1.1. Встановлення цілей та } \\
\text { стратегічних завдань }\end{array}$ & 4 & 4 & 3 & 4 & 4 & 2 & 3 & 1 & 4 & 3 & 2 \\
\hline $\begin{array}{l}\text { 1.2. 3бір та аналіз інформації } \\
\text { про клієнтів та ринок }\end{array}$ & 4 & 3 & 2 & 3 & 4 & 2 & 3 & 2 & 3 & 2 & 1 \\
\hline 1.3. Деталізація бізнес-процесу & 4 & 3 & 2 & 3 & 3 & 2 & 3 & 2 & 4 & 3 & 2 \\
\hline $\begin{array}{l}\text { 1.4. Збір та аналіз інформації } \\
\text { про конкурентів та еталонні } \\
\text { підприємства }\end{array}$ & 4 & 2 & 3 & 3 & 3 & 1 & 3 & 1 & 3 & 2 & 1 \\
\hline 1.5. Планування ресурсів & 4 & 2 & 2 & 3 & 4 & 2 & 3 & 2 & 3 & 3 & 2 \\
\hline Усього, балів & 20 & 14 & 12 & 16 & 18 & 9 & 15 & 7 & 17 & 13 & 7 \\
\hline
\end{tabular}


Таблиця 3

Загальна оцінка якості функцій управління на підприємствах ресторанного бізнесу

\begin{tabular}{|l|c|c|c|c|c|c|c|c|c|c|c|}
\hline \multicolumn{1}{c|}{$\begin{array}{c}\text { Функції } \\
\text { управління }\end{array}$} & $\begin{array}{c}\text { Максимальна } \\
\text { оцінка }\end{array}$ & \multicolumn{9}{|c|}{ Фактична оцінка підпримства } \\
\hline 1. Планування & 20 & 14 & 12 & 16 & 18 & 9 & 15 & 7 & 17 & 13 & 7 \\
\hline 2. Організація & 20 & 15 & 13 & 17 & 19 & 10 & 16 & 8 & 16 & 14 & 8 \\
\hline 3. Мотивація & 20 & 13 & 15 & 16 & 17 & 9 & 14 & 6 & 14 & 13 & 6 \\
\hline 4. Контроль & 20 & 14 & 14 & 16 & 18 & 11 & 15 & 5 & 15 & 15 & 9 \\
\hline 5. Координація & 20 & 13 & 14 & 14 & 17 & 8 & 14 & 7 & 15 & 12 & 7 \\
\hline 3агальна оцінка & 100 & 69 & 68 & 79 & 89 & 47 & 74 & 33 & 77 & 67 & 37 \\
\hline
\end{tabular}

Джерело: розраховано автором

мання та розрахунку всіх необхідних експертних оцінок щодо якості управління за кожною з основних фрункцій $€$ можливість надати оцінку загальній системі управління, що склалася в обстежуваних підприємствах ресторанного бізнесу. У табл. 3. наведено загальну оцінку якості фрункцій управління на підприємствах.

Аналізуючи загальні оцінки якості срункцій управління на підприємствах ресторанного бізнесу можливо зробити висновки, що підприємство «4» займає позицію лідера, підприємства «03», «06», «08» також підтвердили свої позиції в трійки лідерів, підприємства«середняки», до складу яких увійшли підприємства «01», «02» та «09», аутсайдерами таки залишилися підприємства «07» та «10»: за рівнем показників вказані підприємства відстають від максимального результату лідера на п'ятдесят шість та п'ятдесят два бали відповідно, це наочно доводить, що висновки експертів на основі оцінювання однієї з функцій управління, а саме «Планування» виявились вірними і доволі прогнозованими.

Для наочного зображення результатів оцінювання якості фрункцій управління на підприємствах ресторанного бізнесу можна навести графрічне зображення (рис. 2), на яке може бути накладений управлінський профріль організацій, побудований з урахуванням оцінок по кожному з п'яти показників, пропонованої функціональної моделі. На нашу думку, управлінський профріль $є$ графрічним зображенням стану загальної якості менеджменту, що дозволяє ясно побачити напрями, які передусім вимагають детального аналізу та вдосконалення на підприємствах.

Такий підхід дозволяє наочно побачити сильні та слабкі сторони підприємств ресторанного бізнесу, напрями, які вимагають першочергового покращення в системі управління якістю бізнес-процесів [8, с. 394-403].

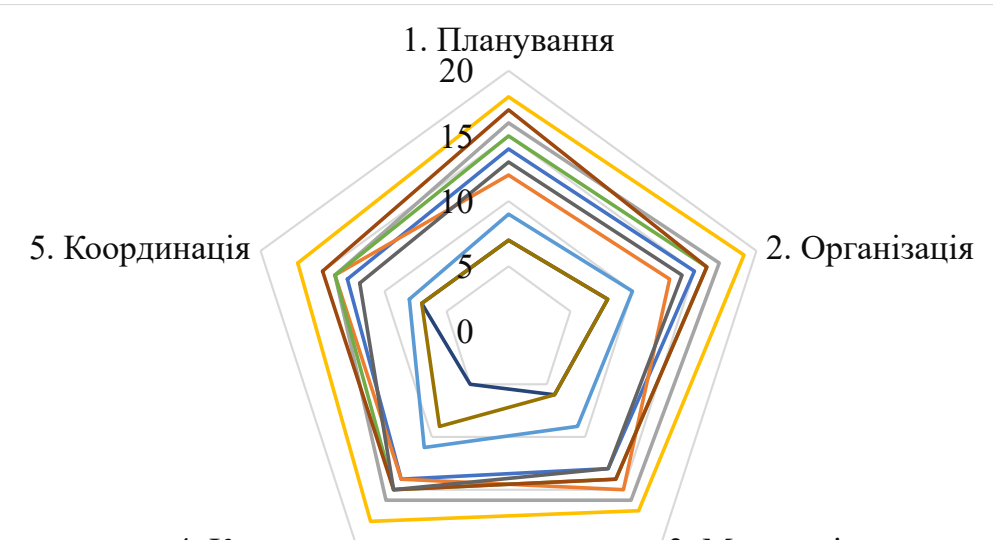

4. Контроль

3. Мотивація

$-1-2-3-4-5-6-7-8-9-10$

Рис. 2. Управлінський профріль стану загальної якості фрункцій управління на підприємствах ресторанного бізнесу 
Таблиця 4

Рівні розвитку якості управління

на досліджуваних підприємствах ресторанного бізнесу

\begin{tabular}{|c|c|c|c|}
\hline Рівень & $\begin{array}{l}\text { Оцінка } \\
\text { (бали) }\end{array}$ & $\begin{array}{c}\text { Підприємства } \\
\text { ресторанного бізнесу }\end{array}$ & Характеристика стану управління \\
\hline 1 & 2 & 3 & 4 \\
\hline I & $(0-20)$ & - & $\begin{array}{l}\text { Управління ведеться безсистемно, цілі не } \\
\text { визначено. Для подальшого розвитку необхідно } \\
\text { суттєво переглянути принципи ведення бізнесу. }\end{array}$ \\
\hline II & $(21-40)$ & 07,10 & $\begin{array}{l}\text { Система управління має потенціал для розвитку, } \\
\text { проте ці можливості реалізуються слабо. } \\
\text { Керівництву необхідно, проявивши ініціативу, } \\
\text { виразно визначити цілі та розробити стратегію } \\
\text { розвитку системи менеджменту на основі якості. }\end{array}$ \\
\hline III & $(41-60)$ & 05 & $\begin{array}{l}\text { Систему управління на підприємстві } \\
\text { сформовано. Необхідно акцентувати увагу на } \\
\text { оптимізації бізнес-процесу та поліпшенні якості } \\
\text { на кожному його етапі. Удосконалюючи систему } \\
\text { управління, варто враховувати важливість } \\
\text { споживача та персоналу. }\end{array}$ \\
\hline IV & $(61-80)$ & $01,02,03,06,08,09$ & $\begin{array}{l}\text { Постійне вдосконалення якості управління } \\
\text { ведеться по більшості напрямів. Необхідно } \\
\text { підтримувати динаміку поліпшення та розпочати } \\
\text { перетворення проблемних сорер діяльності, що } \\
\text { залишилися, використовуючи бенчмаркінг та інші } \\
\text { стратегії вдосконалення. }\end{array}$ \\
\hline $\mathrm{V}$ & $(81-100)$ & 04 & $\begin{array}{l}\text { Досягнуто максимальні результати по всіх } \\
\text { напрямах управлінської діяльності, система } \\
\text { управління є еталонною. }\end{array}$ \\
\hline
\end{tabular}

Джерело: складено авторами

Зображений на рисунку 2 управлінський профріль підприємств, указує, які з досліджених підприємств мають проблеми 3 той чи іншою з функцій управляння. Саме ці напрями загального оцінювання якості управління вимагають детального аналізу та вдосконалення на конкретному підприємстві.

Методичний підхід, який пропонуємо, передбачає визначення інструментарію оцінювання рівнів якості управління та їх вплив на загальний стан якості менеджменту в конкретному підприємстві галузі [9, с. 105-106]. Згруповані результати експертних оцінок щодо якості фрункцій управління на досліджених підприємствах дають змогу отримати більш точну картину стану управлінської роботи. У межах методології нашого підходу можна виділити п'ять рівнів розвитку (зрілості) якості управління на досліджуваних підприємствах [10, с. 89-93]. Імплементацію результатів дослідження щодо рівнів розвитку якості управління на обраних підприємствах ресторанного бізнесу та узагальнену характеристику стану управління наведено в табл. 4.

Висновки. Отже, досвід експериментальної перевірки запропонованого підходу щодо оцінювання якості функцій управління на десяти дослі- джуваних підприємствах ресторанного бізнесу показує, що пропоновані авторські підходи та методика дослідження здатні сорормувати сучасний інструментарій щодо діагностики поточного стану якості системи управління на підприємстві, виявляти його сильні та слабкі сторони.

Отже, аналізуючи якість фрункцій управління по десяти підприємствах ресторанного бізнесу, можна зробити наступні висновки: підприємства «07», «10» знаходяться на II рівні, підприємство «05» - на III, «01», «02», «03», «06», «08», «09» знаходяться на IV рівні розвитку якості фрункцій управління на підприємстві, а лідером є підприємство «04» яке відповідно аналізу опинилося на $\mathrm{V}$ рівні.

На нашу думку, підприємство, яке візьме на озброєння дану методику має шанс покращити свої бізнес-результати та отримати певні конкурентні переваги на цільовому ринку. Оцінювання якості управління повинно стати невід'ємною частиною процесного менеджменту на підприємствах ресторанного бізнесу. Виходячи з цього, кожне підприємство ресторанного бізнесу, що прагне досягти поставленої мети, повинне розробити та впровадити есективну систему оцінювання якості функцій управління. 


\section{СПИСОК ВИКОРИСТАНИХ ДЖЕРЕЛ:}

1. Сівашенко Т. В., Панасюк І. П. Теоретичні засади управління бізнес-процесами у підприємствах ресторанного господарства. Приазовський економічний вісник. 2019. Вип. 3(14). С. 237-244.

2. Крамар М. С., Щербак В. Г. Оптимізація управління бізнес-процесами підприємств в Україні / Актуальні проблеми інноваційного розвитку кластерного підприємництва в Україні : матеріали III-ої Всеукр. наук.-практ. конфр., 28 березня 2019 р. Київ : КНУТД, 2019. С. 86-92.

3. Рибалко-Рак Л. А., Ляшко Н. І. Нова фрілософрія тотального управління якістю: напрями фрормування конкурентоспроможного персоналу для підприємств сфери туризму. Проблеми фрормування та розвитку інноваційної інфрраструктури: виклики постіндустріальної економіки : матеріали IV Міжнар. наук.-прак. конор., 18-19 травня 2017 р. Львів: Львівська політехніка, 2017. С. 543-544.

4. Денисенко М. П., Терещенко Н. М. Формування системи управління якістю послуг у ссрері туризму. Наукові праці МАУП. 2014. Вип. 1(40). С. 134-138.

5. Каплан Роберт, Дейвид Нортон. Сбалансированная система показателей. От стратегии к действию. Москва : ЗАО «Олимп - Бизнес», 2004. 271 с.

6. Alstayn M., Parker Dzh., Chaudari S. Network effect as a new engine of the economy. Harvard Business Review, January-February, (pp. 21-29). IECS. 2017.

7. Отенко І. П., Харнам М. В., Шкребень Р. П. Формування концептуальної моделі управління фрінансовоекономічною безпекою бізнес-процесів підприємства. Бізнес Інфрорм. 2020. № 12 С. 423-429.

8. Lemaska-Majdzik A., Okreglicka M. Identification of Business Processes in an Enterprise Management. In Economic Prospects in the Context of Growing Global and Regional Interdependencies, Proceedings of the 22th International Economic Conference (pp. 394-403). IECS. 2015.

9. Барановська С. В., Ружицький А. А., Михайлович Ю. В. Роль сфери послуг в економіці України. Актуальні задачі сучасних технологій : VIII Міжнародна науково-технічна конфреренція молодих учених та студентів. 2019. С. 105-106.

10. Ареф'єв С. О., Поцелуйко В. А. Бізнес-процеси підприємства: сутність та класифікація. Формування ринкових відносин в Україні. 2017. № 12. С. 89-93.

\section{REFERENCES:}

1. Sivashenko T. V., Panasyuk I. P. (2019) Teoretichni zasadi upravlinnya biznes-protsesami u pidpriemstvakh restorannogo gospodarstva [Theoretical principles of business process management in restaurants]. Priazovs'kii ekonomichnii visnik, 3(14), 237-244. Retrieved from: http://pev.kpu.zp.ua/journals/2019/3_14_uk/40.pdf (in Ukrainian)

2. Kramar M. S., Shcherbak V. G. (2019) Optimizatsiya upravlinnya biznes-protsesami pidpriemstv v Ukraini [Optimization of business process management of enterprises in Ukraine]. Actual problems of innovative development of cluster entrepreneurship in Ukraine: material of the III All-Ukrainian. scientific-practical conf., Kiev, 28th march 2019): KNUTD, pp. 86-92. Retrieved from: https://er.knutd.edu.ua/bitstream/123456789/14757/1/ Cluster2019_P086-092.pdf (in Ukrainian)

3. Ribalko-Rak L. A., Lyashko N. I. (2017) Nova filosofiya total'nogo upravlinnya yakistyu: napryami formuvannya konkurentospromozhnogo personalu dlya pidpriemstv sferi turizmu [New philosophy of total quality management: directions of formation of competitive personnel for enterprises in the field of tourism]. Problemi formuvannya ta rozvitku innovatsiinoï infrastrukturi: vikliki postindustrial'noï ekonomiki: material of the IV International. scientific-practical conf., (Lviv, may 18-19th, 2017), Lviv. politechnik. Retrieved from: https://lpnu.ua/sites/default/files/2020/9/17/ paragraphs/814/tezydopovideyivmnpk.pdf (in Ukrainian)

4. Denisenko M. P., Tereshchenko N. M. (2014) Formuvannya sistemi upravlinnya yakistyu poslug u sferi turizmu [Formation of a quality management system for services in the field of tourism]. Naukovi pratsi MAUP - Scientific works of IAPM, 1(40), 134-138. Retrieved from: http://journals.maup.com.ua/journal/40_2014/4.pdf (in Ukrainian)

5. Kaplan Robert, Deivid Norton (2004) Sbalansirovannaya sistema pokazatelei [Balanced scorecard]. Ot strategii k deistviyu - From strategy to action. Moskow: ZAO «Olimp - Biznes». Retrieved from: https://pqm-online.com/ assets/files/lib/books/norton1.pdf (in Russian)

6. Alstayn M., Parker Dzh., Chaudari S. (2017) Network effect as a new engine of the economy. Harvard Business Review, January-February, (pp. 21-29). IECS Harvard Business Review, January/February 2017 (hbr.org).

7. Otenko I. P., Kharnam M. V., Shkreben' R. P. (2020) Formuvannya kontseptual'noi modeli upravlinnya finansovo-ekonomichnoyu bezpekoyu biznes-protsesiv pidpriemstva [Formation of a conceptual model of financial and economic security management of business processes of the enterprise]. Business Inform, 12, 423-429. DOI: https://doi.org/10.32983/2222-4459-2020-12-423-429 (in Ukrainian) 
8. Lemaska-Majdzik A., Okreglicka M. (2015) Identification of Business Processes in an Enterprise Management. In Economic Prospects in the Context of Growing Global and Regional Interdependencies, Proceedings of the 22th International Economic Conference (pp. 394-403). DOI: https://doi.org/10.1016/S2212-5671(15)01011-4

9. Baranovs'ka S. V., Ruzhits'kii A. A., Mikhailovich Yu. V. (2019) Rol' sferi poslug v ekonomitsi Ukraini. V Aktual'ni zadachi suchasnikh tekhnologii [The role of services in the economy of Ukraine. In Actual problems of modern technologies]: VIII Mizhnarodna naukovo-tekhnichna konferentsiya molodikh uchenikh ta studentiv - VIII International scientific-technical conference of young scientists and students (pp. 105-106). Retrieved from: http://elartu.tntu.edu.ua/ bitstream/lib/31070/2/MNTKv3_2019v3_Baranovska_S_V-Role_of_services_in_105-106.pdf (in Ukrainian)

10. Aref'jev S. O., Pocelujko V. A. (2017) Biznes-procesy pidpryjemstva: sutnistj ta klasyfikacija [Business processes of the enterprise: essence and classification]. Formuvannja rynkovykh vidnosyn $v$ Ukrajini - Formation of market relations in Ukraine, 12, 89-93. Retrieved from: http://nbuv.gov.ua/UJRN/frvu_2017_12_19 (in Ukrainian) 